\title{
Assessment of Response Reduction Factor of Flat Slab Structures by Pushover Analysis
}

\author{
Ajinkya M. Balate, H. R. MagarPatil
}

\begin{abstract}
India is rapidly developing in every aspect now. As a result of which number of smart cities are now arising. while building such smart cities major role is played by infrastructural development. In this infrastructures, speedy and economical constructions are expected to make them more effective. Among such effective construction systems, Flat slab system is the one and is being widely applied on large scale. Flat slabs are thin solid reinforced concrete slabs which are supported directly by columns without beams. Flat slab system is now well adopted for constructions of high rise multi- storied commercial, residential, institutional buildings. They have adventitious constructive, architectural and economical features including easier formwork, speed of construction, spaciousness, etc. The purpose of this project is to study the seismic behavior of Flat Slab Structure for different seismic zones by assessment of Response Reduction Factor using Pushover analysis. Response reduction factor is the factor by which intensity of seismic waves produced during earthquake (maximum elastic base shear) can be reduced to calculate the design base shear. In the project parameters such as base shear, shear and bending stresses and deflection check in flat slab structure are examined by using ETABS Software.
\end{abstract}

Keywords: Base Shear, ETABS Software, Flat Slab, Pushover analysis and Response Reduction Factor.

\section{INTRODUCTION}

The tern Flat Slab denotes the slab with or without drop panels and generally beamless is directly resting upon the columns with or without column capitals (heads). Flat slabs are proving more effective over the traditional slab-beam-column structure system and are being used in the constructions where large amount of free space is demanded as theatres, auditoriums, showrooms and complex. During the seismic activities of earthquake, lateral forces act upon the building. And these lateral forces generate the base shear within the slab structure. High intensity of such forces which leads to the direct or indirect effect on structures and damage to structural and non-structural members. Flat slab structures may face the failures such as flexural failure, punching shear failure, etc. So as to reduce the intensity of such lateral forces response reduction factor(R) is useful. Response reduction factor is ratio of elastic base shear to the design base shear. It is also stated as product of ductility factor, strength factor,

Revised Manuscript Received on July 10, 2020.

* Correspondence Author

Dr. H. R. Magar Patil*, Professor, School of Civil Engineering, Dr. Vishwanath Karad MIT World Peace University, Pune, India.

Ajinkya M. Balate, M.Tech., Department of Structural Engineering, Maharashtra Institute of Technology, World Peace University, Pune, India.

(c) The Authors. Published by Blue Eyes Intelligence Engineering and Sciences Publication (BEIESP). This is an open access article under the CC BY-NC-ND license (http://creativecommons.org/licenses/by-nc-nd/4.0/) structural redundancy and damping associated with the structural behavior.in other way R factor reflects capacity of slab structure to dissipate energy due to above mentioned forces by its inelastic behavior.

$\mathrm{R}$ factor goes on decreasing as the number of stories increases. but $\mathrm{R}$ factor for Flat slab system is not stated in Indian Standard (IS) code. Here in this paper the assessment of response reduction factor is done for behavior of flat slabs at seismic zones II, III and IV by pushover analysis. ETABS software is used to analyse the flat slab structure.

\section{OBJECCTIVES}

- The present article represents analytical study to evaluate the response reduction factors of eight storey flat slab building by using ETABS software.

- To analyse the flat slab building using pushover analysis method for different response reduction factors and seismic zones.

- To determine the base shear for different $\mathrm{R}$ values using ETABS and manual for calculation validation.

- Also comparative examination of bending stress and to check the deflection in serviceability case for flat slab building.

\section{LITURATURE REVIEW}

Literature survey stated below is comprised of summary of research papers presented in various popular journals on the topic similar to current field of study. Kunal P. Shukla[1],This paper related to evaluation of response reduction factor of RCC building based on plastic design methodology and limit state method. The prevention of the total collapse of structure can be performed based on plastic design method, which uses pre-selected target drift \& yield mechanism, it is criteria for performance of structure. In this paper author select a fifteen storey RCC frame structure was designed using performance based plastic design methodology and now currently used limit state design which is force based method. The comparative study of seismic performance evaluation of frames was then carried out by determining Response reduction factor as well as failure pattern. Abhijit Salunkhe[2],Flat slabs are system of construction is one in which the beams used in the conventional methods of constructions are done away with, Flat slab structure have advantages over conventional structure such as economy in construction, its architectural appearance,

Published By:

Blue Eyes Intelligence Engineering

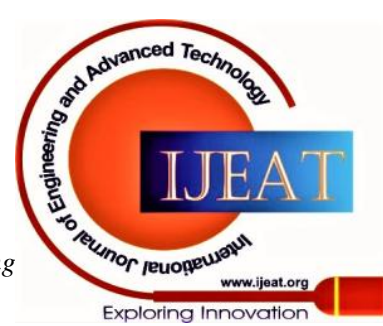


flexibility and speed of the construction. However, because of extraction of beams from flat slab system, reduction in lateral stiffness, hence flat slab structure more flexible to seismic loading as compare with conventional structure. The aim of this work is to compare the seismic behavior of flat slab structure with conventional frame structure. R. P. Apostolska. and G. S. Necevska- Cvetanovska [3],They work on Seismic Performance of Flat-Slab Building Structural Systems and conclude that the purely flat-slab RC structural system is considerably more flexible for horizontal loads than the traditional RC frame structures which contributes to the increase of its vulnerability to seismic effects. Salman I. Khan and Ashok R. Mundhada.[4],The objective of the study is to achieve the comparative seismic performance of flat slab buildings with grid slab buildings. Dynamic analysis of three different high-rise buildings having 12, 15 \& 18 stories is performed using response spectrum method for all four seismic zones of India, as categorized by the Indian code for earthquake resistant structures. The assessment of the seismic response is based on the maximum inter-story drift, roof displacement, Time period and the base shear. E-TAB v9.7.3 software is used for the analysis. It is observed that the seismic performance of grid slab buildings was better performance against earthquake load case as compared to that of flat slab buildings. P. Srinivasulu,[5],The flat slab system is currently widely used in commercial building construction. It permits flexibility in architecture, clear height is more, lowers the building height, easier formwork, and speedy construction. Flat slab building structures are naturally more flexible than conventional concrete structures as beams are absent. They are becoming more vulnerable to earthquakes. The objective of this paper is to investigate the behavior of flat slab in 4 different cases as I). Flat slab structure without drop, II). Flat slab structure with column drop, III). Flat slab structure with shear wall, IV). The flat slab structure with column drop and structural shear wall combination, by response spectrum method, by using ETABS software. The behavior of the flat slab is worked out in terms of story displacements, frequency of structure, base shear of building, story level accelerations. And also, most major problem in flat slabs is punching shear failure around the column head. Mohan H. S.[6] Now a days, construction activity the use of flat slab is absolutely common which helps to weight reduction, speedy construction and economical. Its's capacity is similar from the earlier conventional slab providing features like more stiffness, higher the load carrying capacity \& safe also. This paper based on G+5 commercial multistoried building having flat slab \& conventional slab have been analyzed for the parameters like base shear, storey drift, axial forces \& the displacement. The performance and the structural behavior of both the system in all seismic zones of India have been studied. The conclusion of work was the storey shear of flat slab gives $5 \%$ more than the conventional slab structure, axial forces are nearly 6\% more than conventional building. Pradip S. Lande,[7],In this paper the parametric investigation was carried out to study seismic response of the system which are as flat slab building, flat slab with perimeter beam, flat slab with shear wall, flat slab with drop panel \& conventional building hypothetical systems were studied for two different storey heights located in sever zone $\mathrm{V}$ and analysis was

Retrieval Number: F1355089620/2020@BEIESP

DOI: 10.35940/ijeat.F1355.089620

Journal Website: www.ijeat.org carried out in ETABS nonlinear. Mohammad Hossain1, Tahsin Hossain,[8], They investigated in their research the effect of column on flat plate structure. Also, they have studied the effect of other parameter in different flat plat model in ETABS software. The different parameter is used in study are Height of column, Column have different cross-section with three different panel sizes for gravity and environmental load. They have investigated critical buckling load variation and ultimate load to critical buckling load variation along with non-sway moment magnification factor variation, sway moment magnification factor variation for different location of column. Navyashree K,[9]They study for conventional R.C.C building and flat slab building for different floor height in the seismic regions. The effect of seismic load on structure has been studied for the two types of building with different height. They conclude that the moments are maximum at plinth, first and second level. After second level it decreases and increases at the top storey level. The column behavior changes as height of the building structure increases. Storey drift in building with flat slab construction is significantly more as compared to regular R.C.C building. As a result of this, additional moments are developed there. Therefore, the columns of such buildings should be designed by considering additional moments caused by the drift effect. The difference between the two varies from 28-60 percent. Micallef K., Sagaseta J,[10]They worked on punching shear failure in RCC flat slab subjected to impact loading. They had studied the dynamic behavior of slab for different parameter like with and without transverse reinforcement in it. In this study they have presented different experimental work on flat slab for evaluate punching shear in flat slab subjected to impact loadings. They have presented stiffness and response of slab during experiments. From their result it has been seen that increase in stiffness due to variation in slab span.

\section{METHODOLOGY}

\section{A. Modelling of structure}

Building model purposed project is having $\mathrm{G}+7$ storey with floor to floor $3.5 \mathrm{~m}$. A simple $37.1 \mathrm{~m}$ X $26.5 \mathrm{~m}$ plan was prepared for flat slab structure. Panel size of this structure is $5.3 \mathrm{~m}$ X $5.3 \mathrm{~m}$.The fixed supports are used as end conditions to all the columns. Brick material of siporex block of grade 1 with density $9 \mathrm{kN} / \mathrm{m}^{3}$ is used for partition wall. Steel and concrete used have grades Fe415 and M25 respectively. ETABS software is used here for all designs and model analysis. Models having different response reduction factor are created using ETABS. Modulus of elasticity of steel is 2 $\mathrm{X} 105 \mathrm{~N} / \mathrm{mm}^{2}$.

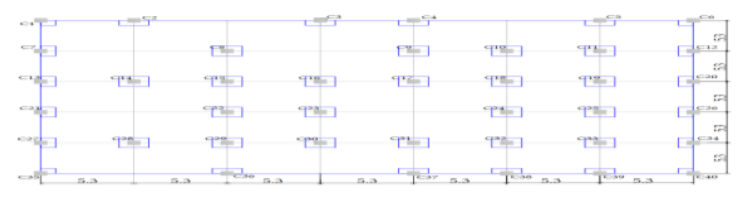

Fig. 1.Floor plan of Flat slab building.

Published By:

Blue Eyes Intelligence Engineering \& Sciences Publication (C) Copyriaht: All riahts reserved.

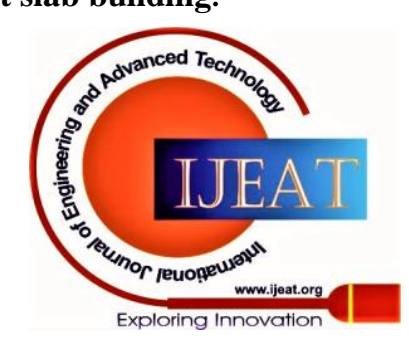




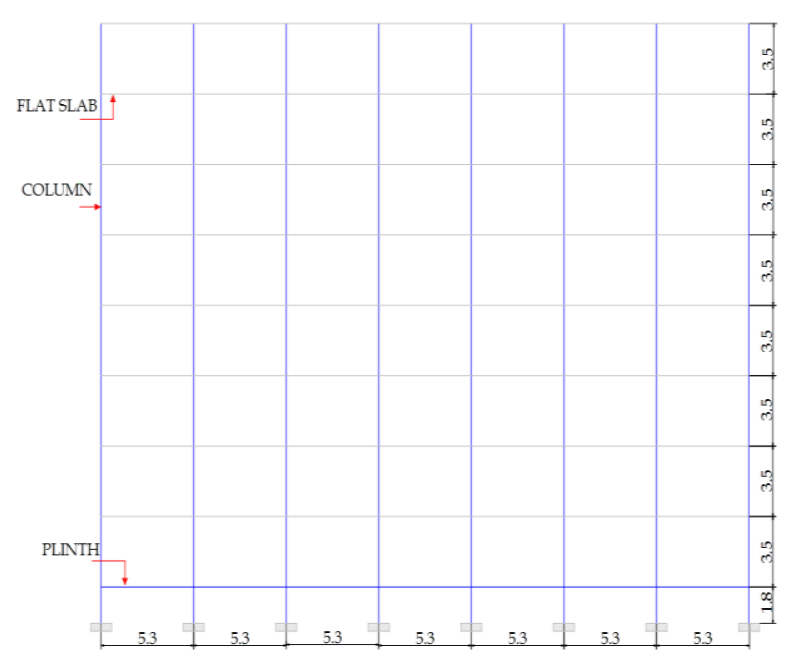

Fig. 2. Elevation of Flat slab building.

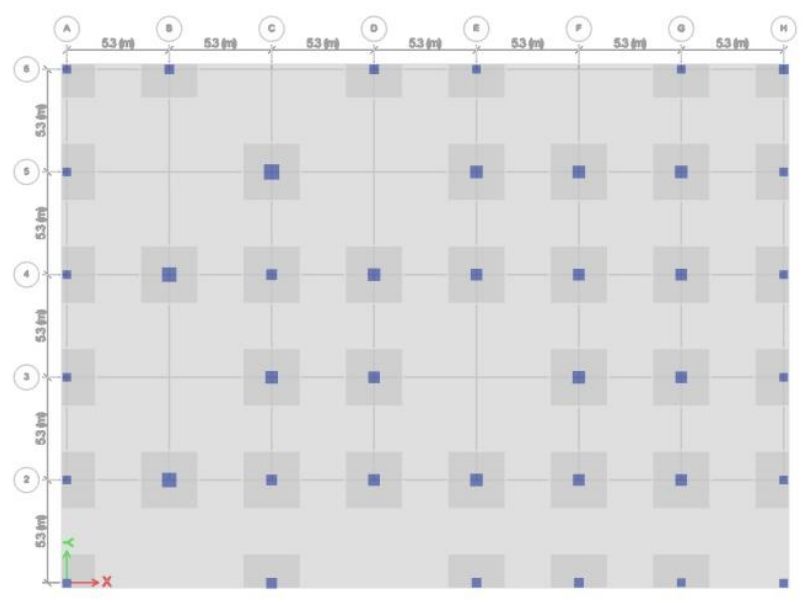

Fig. 3. Model plan drop view for Flat slab building.

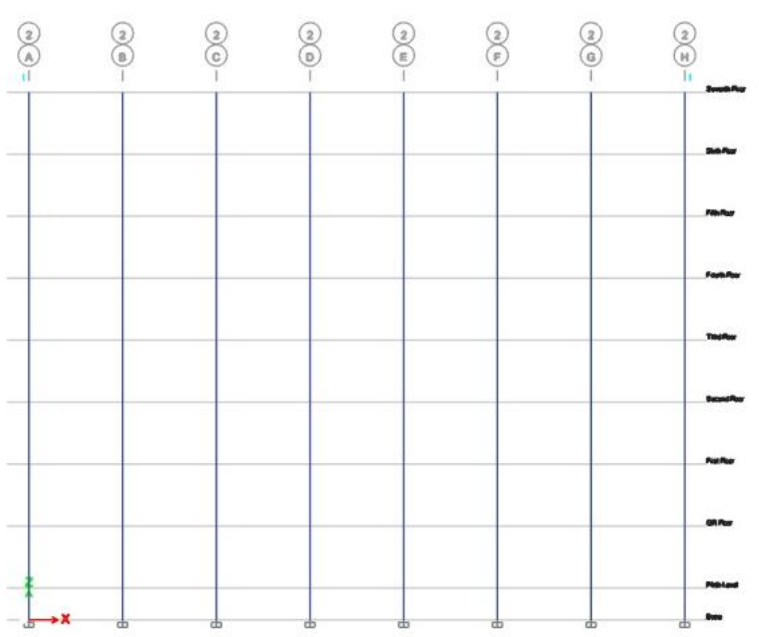

Fig. 4. Model elevation view for Flat slab building. Table- I: Flat slab Structure element details

\begin{tabular}{|l|l|}
\hline Flat slab (thickness) & $250 \mathrm{~mm}$ \\
\hline Drop size & $1.7 \mathrm{~m} \mathrm{x1.7m}$ \\
\hline Drop thickness & $125 \mathrm{~mm}$ \\
\hline Thickness of wall & $150 \mathrm{~mm}$ \\
\hline Plinth beam & $300 \mathrm{~mm} \times 450 \mathrm{~mm}$ \\
\hline
\end{tabular}

Table- II: Flat slab column details

\begin{tabular}{|c|l|}
\hline $\begin{array}{c}\text { Column size } \\
(\mathrm{mm})\end{array}$ & \multicolumn{1}{|c|}{ Column size } \\
\hline $450 X 450$ & $\begin{array}{l}\text { C1,C4,C5,C7,C12,C13,C20,C21,C26, } \\
\text { C27,C34,C35,C39,C40 }\end{array}$ \\
\hline $500 X 500$ & C2,C3,C6,C37,C38 \\
\hline $550 X 550$ & C15,C29,C36 \\
\hline $600 X 600$ & C17,C18,C19,C23,C25,C30,C32,C33 \\
\hline $650 X 650$ & C9,C10,C11,C16,C22,C24,C31 \\
\hline $750 X 750$ & C14,C28 \\
\hline $800 X 800$ & C8 \\
\hline
\end{tabular}

B. Earthquake and other loads

Table- III: Earthquake and loads

\begin{tabular}{|c|l|}
\hline Seismic zone & II,III,IV \\
\hline Response reduction factor R & $1,2,3,4,5$ \\
\hline Importance factor I & 1 \\
\hline Damping ratio & $5 \%$ \\
\hline Type of soil & Hard \\
\hline Live load & $3 \mathrm{kN} / \mathrm{m}^{2}$ \\
\hline Dead load & $6.5 \mathrm{kN} / \mathrm{m}^{2}$ \\
\hline Flat slab & $1 \mathrm{kN} / \mathrm{m}^{2}$ \\
\hline Floor finish & $2.28 \mathrm{kN} / \mathrm{m}^{2}$ \\
\hline Wall load & $0.16 \mathrm{kN} / \mathrm{m}^{2}$ \\
\hline Parapet wall load &
\end{tabular}

\section{Loading combination}

Loading combination as per IS: 1893 are given below-

- 1.5DL + 1.5LL

- 1.5DL $\pm 1.5 \mathrm{EQx}$

- 1.5DL $\pm 1.5 \mathrm{EQz}$

-1.2DL + 1.2LL $\pm 1.2 \mathrm{EQx}$

-1.2DL + 1.2LL $\pm 1.2 \mathrm{EQz}$

- $0.9 \mathrm{DL} \pm 1.5 \mathrm{EQx}$

- $0.9 \mathrm{DL} \pm 1.5 \mathrm{EQz}$

As per IS: 456 Load combination used for limit state of serviceability to check the deflection of structure-

- DL+LL

- $\mathrm{DL}+\mathrm{EQx}$

- $\mathrm{DL}+\mathrm{EQz}$

- $\mathrm{DL}+0.8 \mathrm{LL}+0.8 \mathrm{EQx}$

- $\mathrm{DL}+0.8 \mathrm{LL}+0.8 \mathrm{EQz}$

Where, EQX and EQZ are Earthquake loads DL is Dead load and LL is Live load.

Published By:

Blue Eyes Intelligence Engineering

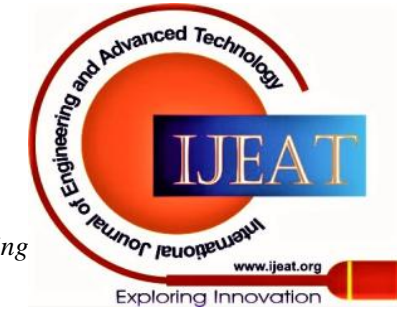




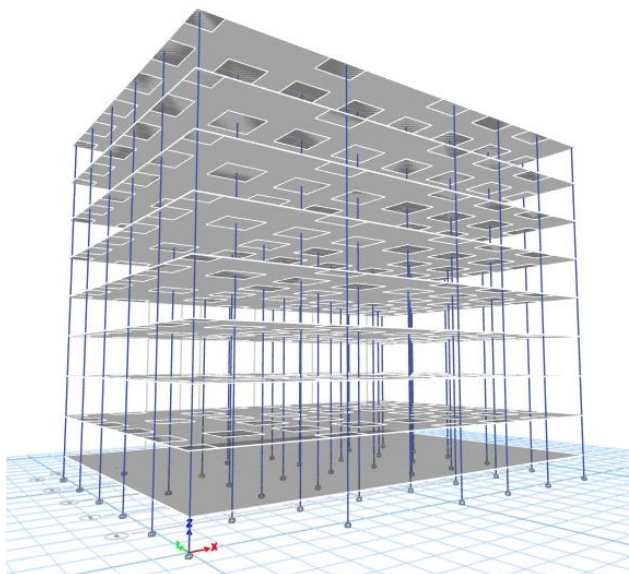

Fig. 5. Isometric view for Flat slab building in ETABS.

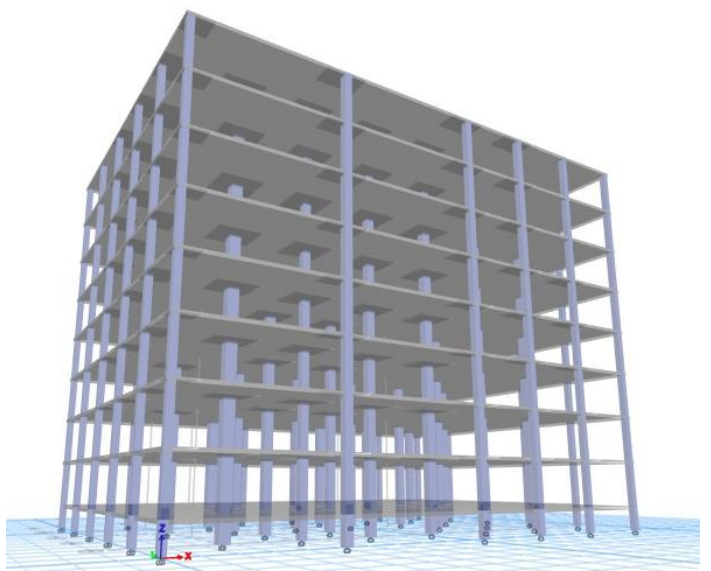

Fig. 6. Model 3D view for Flat slab building in ETABS.

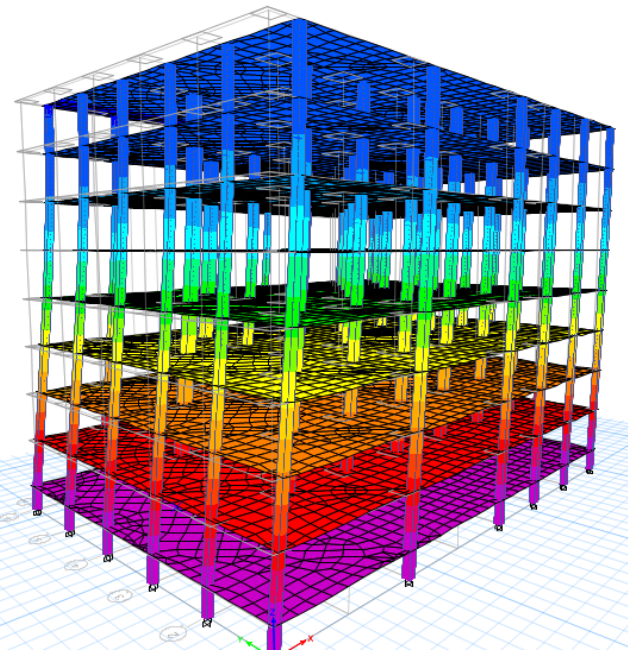

Fig. 7. Seismic load view for Flat slab building.

\section{RESULT AND DISSCUSION}

\section{A. Result graph comparison}

Graphs are plotted by comparing the bending moment in the slab with bending moment and similar comparison are plotted for $\mathrm{R}=1,2,3,4,5$ and zone II, III, IV.

1. Graphical comparison of bending moment of flat slab for load case $1.5(\mathrm{DL}+\mathrm{LL})$ with $1.5(\mathrm{DL}+\mathrm{Eq} . \mathrm{X})$ which is critical load case for $\mathrm{R}=1,2$, 3, 4, 5 considering zone II

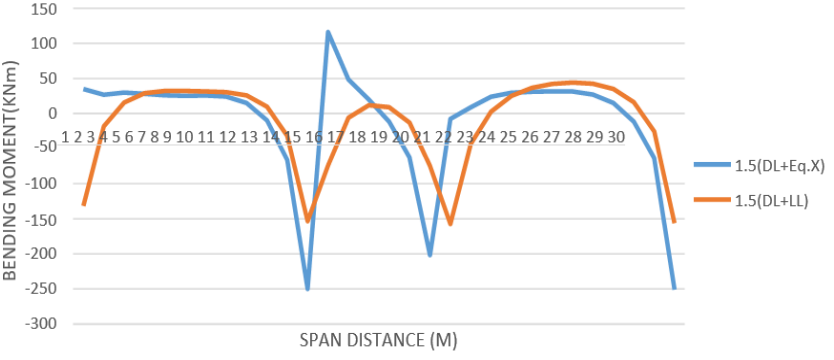

Fig. 8. For flat slab 1.5(DL+Eq.X) with 1.5(DL+LL) for $\mathbf{R}=\mathbf{1}$.

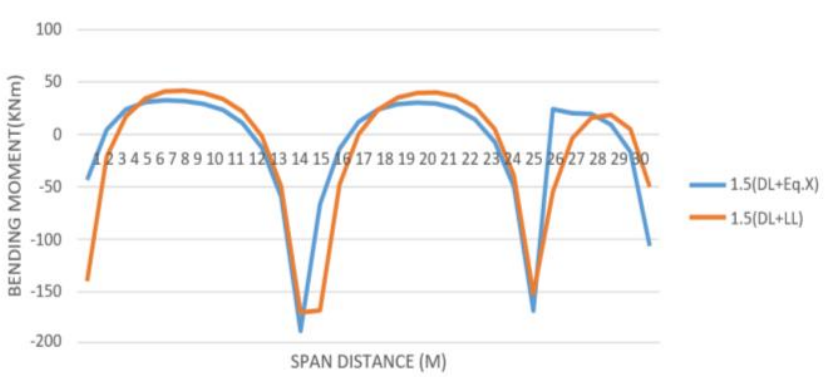

Fig. 9. For flat slab 1.5(DL+Eq.X) with 1.5(DL+LL) for $\mathbf{R}=\mathbf{2}$.

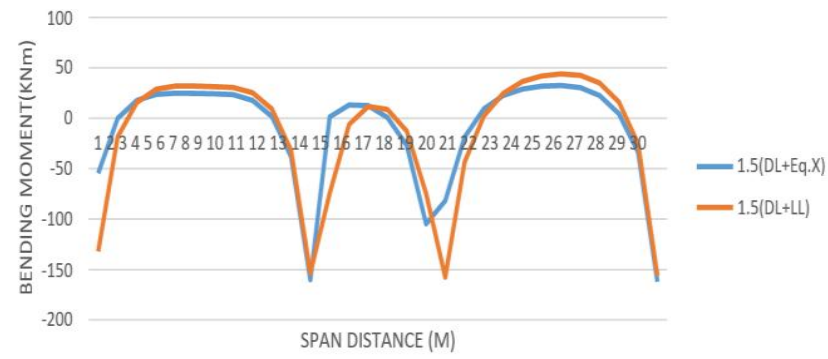

Fig. 10. For flat slab 1.5(DL+Eq.X) with 1.5(DL+LL) for $R=3$.

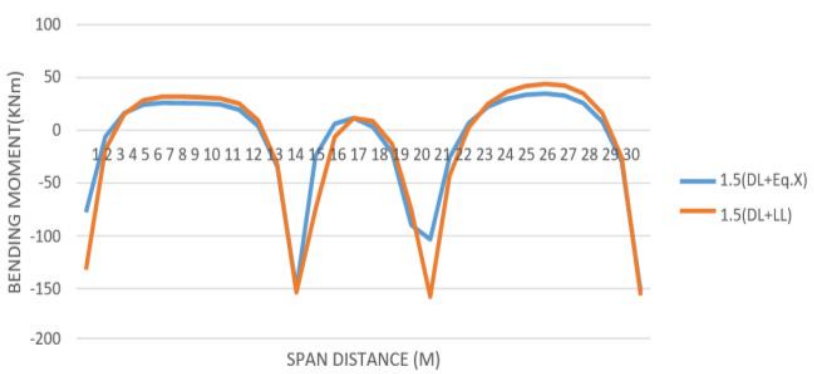

Fig. 11. For flat slab 1.5(DL+Eq.X) with 1.5(DL+LL) for $R=4$.

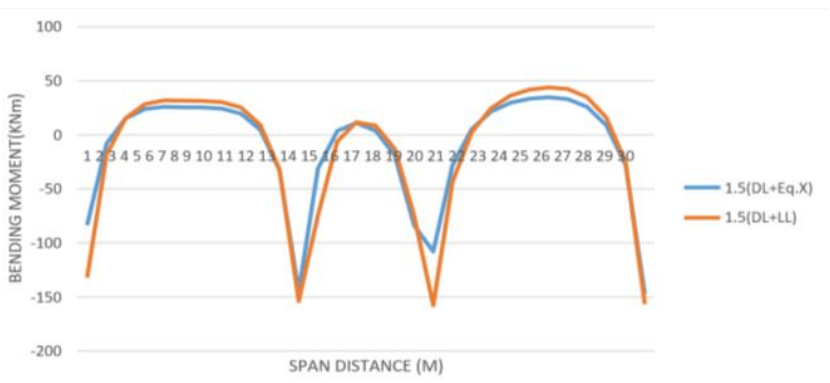

Fig. 12. For flat slab 1.5(DL+Eq.X) with 1.5(DL+LL) for $R=5$.

Published By:

Blue Eyes Intelligence Engineering \& Sciences Publication

(c) Copyriaht: All riahts reserved.

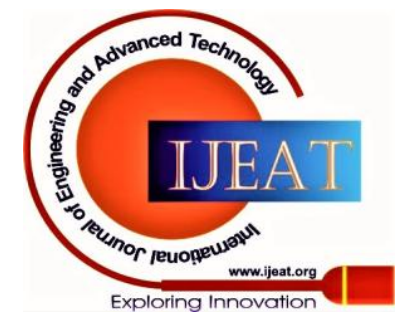


2. Graphical comparison of bending moment of flat slab for load case $1.5(\mathrm{DL}+\mathrm{LL})$ with $1.5(\mathrm{DL}+\mathrm{Eq} . \mathrm{X})$ which is critical load case for $\mathrm{R}=3$ considering zone III

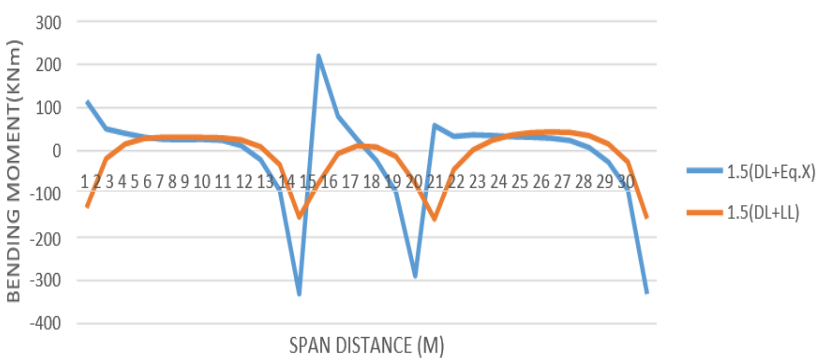

Fig. 13. For flat slab 1.5(DL+Eq.X) with 1.5(DL+LL) for $R=3$.

3. Graphical comparison of bending moment of flat slab for load case $1.5(\mathrm{DL}+\mathrm{LL})$ with $1.5(\mathrm{DL}+\mathrm{Eq} . \mathrm{X})$ which is critical load case for $\mathrm{R}=1 \mathrm{Vs} \mathrm{R}=3$, 5 considering zone II

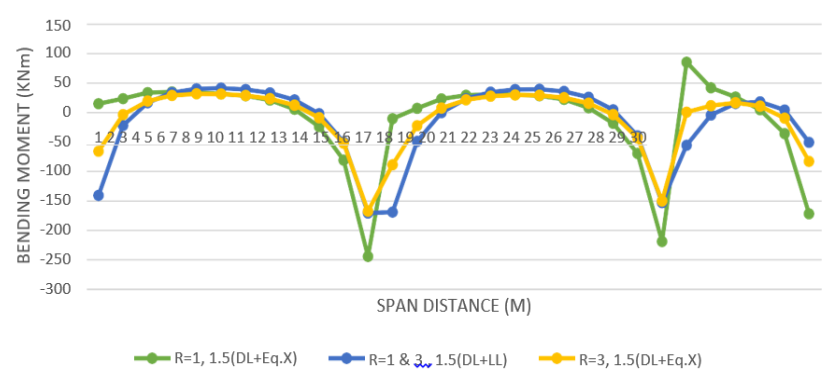

Fig. 14. For flat slab 1.5(DL+Eq.X) with 1.5(DL+LL) for $R=1$ Vs $R=3$.

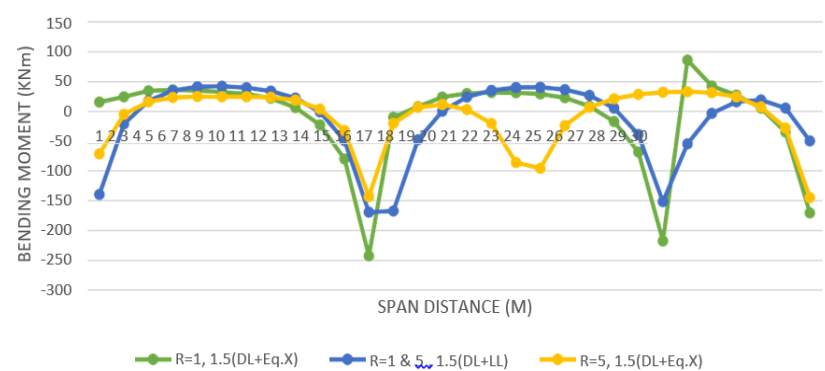

Fig. 15. For flat slab 1.5(DL+Eq.X) with 1.5(DL+LL) for $R=1$ Vs $R=5$.

4. Graphical comparison of bending moment of flat slab for load case $1.5(\mathrm{DL}+\mathrm{LL})$ with $1.5(\mathrm{DL}+\mathrm{Eq} . \mathrm{X})$ which is critical load case for $\mathrm{R}=3$, 5 considering zone II,III,IV

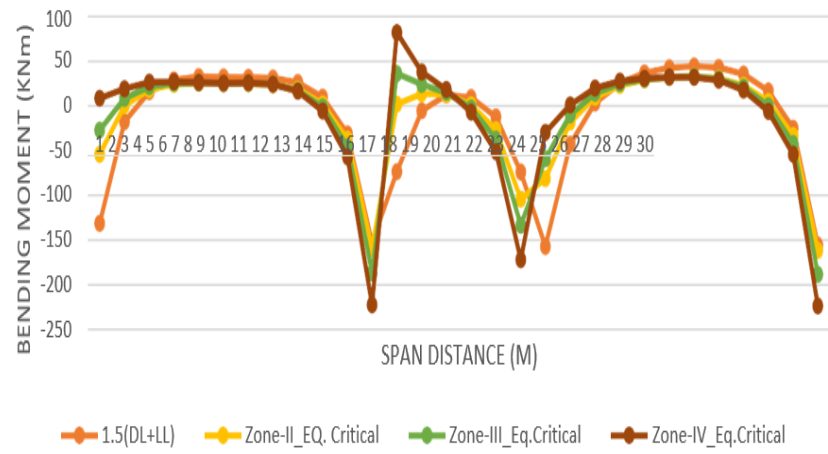

Fig. 16. For flat slab 1.5(DL+Eq.X) with 1.5(DL+LL) for $\mathrm{R}=3$, Zone-II, III, IV.

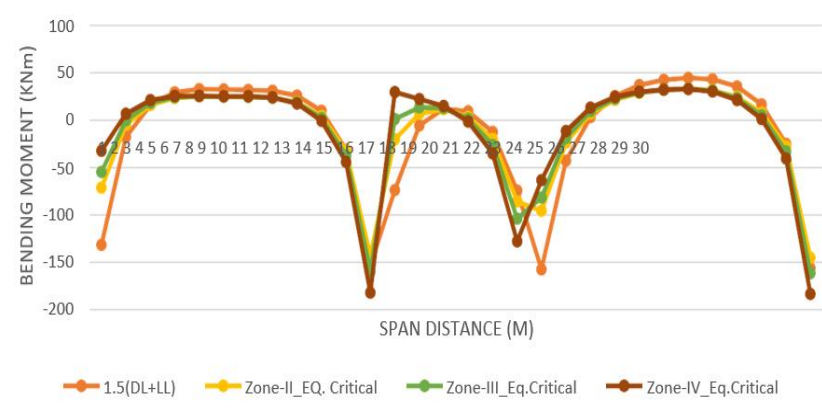

Fig. 17. For flat slab 1.5(DL+Eq.X) with 1.5(DL+LL) for $\mathrm{R}=5$, Zone-II, III, IV.

\section{B. Deflection graph for flat slab system}

For stability of slab structure deflection check is necessary, to check the allowable deflection as per IS 456 serviceability load case is considered, as per the final deflection due to loads on structure including temperature, shrinkage and creep should not exceed Span/350 or 20mm whichever is lesser. For this flat slab case span are $5.3 \mathrm{~m}$ and $10.6 \mathrm{~m}$ allowable deflections $15.14 \mathrm{~mm}$ and $30.28 \mathrm{~mm}$ respectively

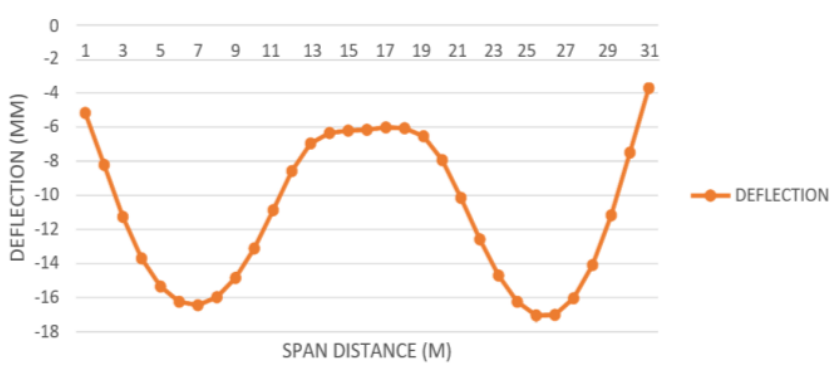

Fig. 18. For flat slab deflection Vs span dist. For R-3 \& zone-II.

In deflection graph we observed that maximum vertical deflection in the slab is $16.63 \mathrm{~mm}$ which is lesser than $20 \mathrm{~mm}$, so the slab is safe against the deflection during serviceability condition.

\section{Lateral deflection for flat slab system}

Lateral stability of the building deflection check is necessary for serviceability load case, as per codal provision the lateral allowable deflection is $0.4 \%$ of the height of storey. The height of flat slab building is $29.80 \mathrm{~m}$ and allowable deflections $119.20 \mathrm{~mm}$.

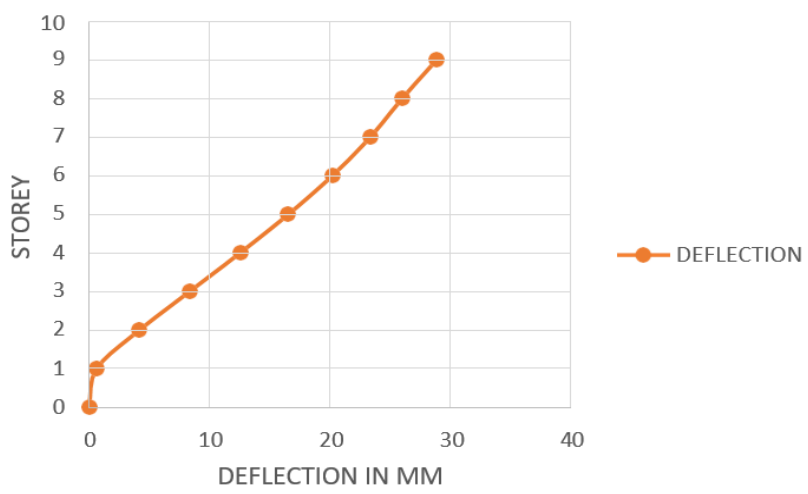

Fig. 19. For flat slab column deflection Vs span dist. For R-3 \& zone-II.

Published By:

Blue Eyes Intelligence Engineering

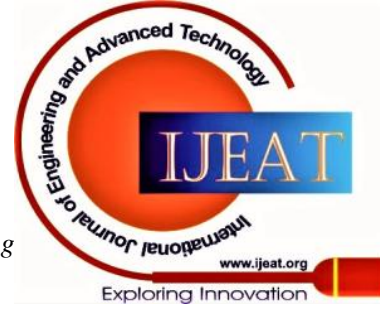




\section{Base shear and horizontal acceleration spectrum for flat slab}

1. Design horizontal acceleration spectrum for Flat Slab

Table- IV: Design horizontal acceleration spectrum Ah for Flat Slab

\begin{tabular}{|l|c|c|c|c|c|}
\hline \multirow{2}{*}{$\begin{array}{c}\text { Seismic } \\
\text { zone }\end{array}$} & \multicolumn{5}{|c|}{ Response reduction factor-R } \\
\cline { 2 - 6 } & 1 & 2 & 3 & 4 & 5 \\
\hline Zone II & 0.0608 & 0.0312 & 0.0224 & 0.0154 & 0.0119 \\
\hline Zone III & 0.0787 & 0.0387 & 0.0258 & 0.0197 & 0.0153 \\
\hline Zone IV & 0.0987 & 0.0589 & 0.0378 & 0.0282 & 0.0208 \\
\hline
\end{tabular}

\section{Design base shear for Flat Slab}

Base shear means lateral forces acting to the base of a structure due to seismic waves, following are the results of base shear $(\mathrm{kN})$ of all models for various $\mathrm{R}$ factors

Table- V: Design Base shear $V_{B}$ ETABS with manual validation for Flat slab structure

\begin{tabular}{|c|c|c|c|c|c|c|}
\hline \multirow{2}{*}{\multicolumn{2}{|c|}{$\begin{array}{c}\text { Seismic } \\
\text { zone }\end{array}$}} & \multicolumn{5}{|c|}{ Response reduction factor- $R$} \\
\hline & & 1 & 2 & 3 & 4 & 5 \\
\hline \multirow{2}{*}{$\begin{array}{c}\text { Zone } \\
\text { II }\end{array}$} & ETABS & $\begin{array}{c}4102.6 \\
9\end{array}$ & $\begin{array}{c}2139.5 \\
3\end{array}$ & $\begin{array}{c}1243.0 \\
1\end{array}$ & 973.68 & 732.83 \\
\hline & $\begin{array}{c}\text { Manua } \\
\text { l }\end{array}$ & $\begin{array}{c}4076.7 \\
9\end{array}$ & $\begin{array}{c}2133.8 \\
9\end{array}$ & $\begin{array}{c}1269.3 \\
7\end{array}$ & 963.44 & 726.39 \\
\hline \multirow{2}{*}{$\begin{array}{c}\text { Zone } \\
\text { III }\end{array}$} & ETABS & $\begin{array}{c}6334.5 \\
8\end{array}$ & $\begin{array}{c}3279.8 \\
6\end{array}$ & $\begin{array}{c}2192.0 \\
7\end{array}$ & $\begin{array}{c}1529.5 \\
6\end{array}$ & $\begin{array}{c}1268.3 \\
2\end{array}$ \\
\hline & $\begin{array}{c}\text { Manua } \\
\text { l }\end{array}$ & $\begin{array}{l}6328.8 \\
7\end{array}$ & $\begin{array}{c}3259.4 \\
7\end{array}$ & $\begin{array}{c}2239.2 \\
8\end{array}$ & $\begin{array}{c}1533.6 \\
3\end{array}$ & $\begin{array}{c}1274.6 \\
2\end{array}$ \\
\hline \multirow{2}{*}{$\begin{array}{c}\text { Zone } \\
\text { IV }\end{array}$} & ETABS & $\begin{array}{c}9324.3 \\
9\end{array}$ & $\begin{array}{c}5139.2 \\
7\end{array}$ & $\begin{array}{c}3089.2 \\
7\end{array}$ & $\begin{array}{c}2763.0 \\
3\end{array}$ & $\begin{array}{c}1827.2 \\
5\end{array}$ \\
\hline & $\begin{array}{c}\text { Manua } \\
1\end{array}$ & $\begin{array}{c}9333.5 \\
1\end{array}$ & $\begin{array}{c}5129.3 \\
4\end{array}$ & $\begin{array}{c}3127.4 \\
9\end{array}$ & $\begin{array}{c}2748.1 \\
2\end{array}$ & $\begin{array}{c}1813.3 \\
8\end{array}$ \\
\hline
\end{tabular}

\section{SUMMURY AND CONCLUSION}

Above comparative results have shown clearly the comparison of flat slab structure having different response reduction factors.

Among the graphs stated above, better results are given by the flat slab structure of zone II having $\mathrm{R}$ factor of 3 . In this design, earthquake case can be considered as critical load case, because the difference between ultimate load case excluding earthquake and ultimate load case of earthquake is minimum or the same value.

The moment which gives safe depth check as per provided depth is considered as ultimate moment, for the design purpose. Similarly, the design moment of above case governs earthquake case is safe under depth check.

It is observed by the above graph, the flat slab gives maximum bending moment at end corner as it behaves similarly to cantilever slab.

Earthquake cases for Zone III and IV, the maximum bending moment is given which gives more difference. In these cases provide more depth then the slab depth. It is also necessary to construct peripheral beam as well as to provide shear wall at the corner of building design so as to improve sustainability of it and will also provide extra bottom steel for slab. Earthquake intensities for zone III and zone IV are more. for that, avoid the multistoried flat slab type of building. For flat slab structure having R-3, we get safe serviceability deflection check. Flat slab structure for R-4 reduces the intensity of earthquake by $40 \%$ while for R-5 reduces it by $50 \%$ which means lateral forces directing upon the building are also reduced. But for that ductile detailing is necessary. As there is no beam construction in pure flat slab so, it can be a problem for providing ductile dealing steel. It is clarified from all above observations that flat slab structure for R-3 reduces the earthquake intensity by $30 \%$ so that it can sustain the building structure during seismic vibrations produce by earthquake. Also, against the limit serviceability and limit state of collapse this structure is safe.

\section{REFERENCES}

1. Kunal P. Shukla 1, Sejal P. Dalal 2, Et. Al (2016), "Evaluation of Response Reduction Factor of Reinforced Cement Concrete Building Designed by Performance Based Plastic Design Method \& Limit State Design Method."

2. Abhijit Salunkhe 1, Dr.D.N.Shinde 2, Et.Al (2016),“A Comparative Study of Seismic Response of Flat Slab Structure and Conventional RC Framed Structure."

3. R.P. Apostolska 1, G.S.Necevska-Cvetanovska 2, J.P. Cvetanovska 3, Et.Al (2015), "Seismic Performance of Flat-Slab Building Structural System."

4. Salman I. Khan 1, Ashok R. Mundhada 2, Et.Al (2015),“Comparative study of Seismic Performance of multistoried R.C.C buildings with Flat slab \& Grid slab."

5. P. Srinivasulu 1, A. Dattatreya Kumar 2, Et.Al(2015), "Behaviour Of Rcc Flat Slab Structure Under Earthquake Loading ."

6. Mohan H.S. 1, Kavan M.R. 2, Et.Al (2015), "Comparative Study of Flat Slab and Conventional Slab Structure Using ETABS for Different Earthquake Zones of India."

7. Pradip S. Lande 1, Aniket B.Raut 2, Et.Al (2015), "Seismic Behaviour of Flat Slab Syatem.”

8. Mohammad Hossain1, Tahsin Hossain 2, Et.Al,(2014), "FEM Approach to Perform Parametric Study on Slender Columns for Flat-Plate Structures."

9. Navyashree K1, Sahana T. S 2, Et.Al(2012) "Use of Flat Slabs in Multi-Storey Commercial Building Situated in High Seismic Zone (2012)"

10. Micallef K.1, Sagaseta J. 2, M., Muttoni A. 3, Et.Al (2014), "Punching of flat slabs supported on rectangular columns."

11. IS 456-2000, Indian Standard Code of Practice for Plain and Reinforced Concrete Bureau of Indian Standard, New Delhi.

12. IS1893 (Part 1)-2002, Indian Standard Code of Practice for Ductile Detailing of Reinforced Concrete Structures Subjected to Seismic Forces. Bureau of Indian Standard, New Delhi.

\section{AUTHORS PROFILE}

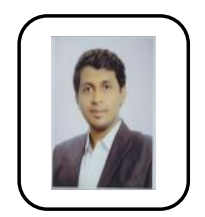

Ajinkya M. Balate. received his Bachelor's degree from the Pune University, India. He is presently pursuing his M.Tech.in Structural Engineering degree from the Maharashtra Institute of Technology, World Peace University, Pune, India. He is a member of The Institution of Engineers (IEI) and Indian Society of Structural Engineers (ISSE). His research interests are Earthquake Engineering, Structural Analysis and Structural Audit. (Email: erambalate@gmai.com)

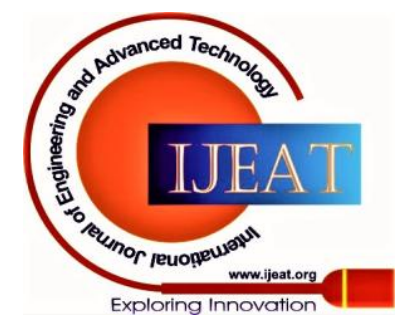




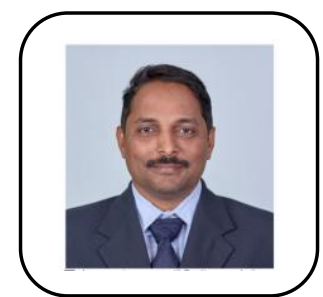

Dr. H. R. Magar Patil. is a Professor in the School of Civil Engineering at Dr. Vishwanath Karad MIT World Peace University, Pune. He has completed his doctoral degree from the Indian Institute Technology (IIT), Bombay in 2016.His Ph.D. research work was in the field of Earthquake Resistant Design of Structures in general and Seismic Response of Steel Moment Resisting Frame installed with Passive Energy Dissipation Devices in particular. He has published two books and over 30 research papers and articles in reputed journals. He is also the recipient of most prestigious awards like Dr. APJ Abdul Kalam research and motivation prize-2019, IACC Innovative Faculty Award-2019, Padmashree B.G. Shirke Vidyarthi Award-2018 for the research and development work in the fields of structural engineering.

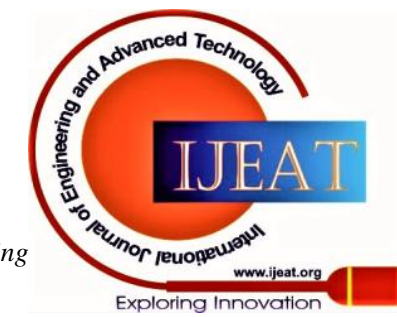

